Supporting Information

\title{
Significantly Enhanced Thermotropic Liquid Crystalline Columnar Mesophases in Stereoregular Polymethylenes with Discotic Triphenylene Side-Groups
}

Xiao $\mathrm{Li}^{\#}$, Bin $\mathrm{Mu}^{\#}$, Changlong Chen, Jian Chen, Jiang Liu, Feng Liu* and Dongzhong Chen*

\section{Table of Contents}

A. Direct Carbene Polymerization Attempts from TP-Based Diazo Monomer with Six-Methylene Spacer

B. Synthesis and Characterization Results of Other Bromoalkyl Diazoacetate Monomers $(m=3,4$, $8,10,12)$

C. ${ }^{1}$ H NMR Spectrum of P3(TP6)

D. ${ }^{1} \mathrm{H}$ NMR Spectra Comparison of the Monomer M6TP6 in Various Concentrations

E. TGA Analysis Results of $\mathrm{P} 6 \mathrm{Br}$ and $\mathrm{P} m(\mathrm{TP} n)(m=3,4,6,8,10,12 ; n=4,6,10)$

F. Thermal Properties of the Precursor Polymers $\operatorname{P} m \operatorname{Br}(m=3,4,6,8,10,12)$

G. Representative POM Images of $\operatorname{P} m \operatorname{Br}(m=3,4,6,8,10,12)$

H. The SAXS/WAXS Diffractograms and Assignments for the Precursor Polymers of $\mathrm{P} m \mathrm{Br}(m=$ $3,4,6,8,10,12)$

I. Representative POM Images of P6(TP6) at Various Temperatures

J. Variable Temperature SAXS/WAXS Diffractograms for P3(TP6) and P12(TP6)

K. Synchrotron Radiation X-Ray Scattering Data and Structure Assignments for the Series C1 Polymethylenes of $\mathrm{P} m(\mathrm{TP} n)(m=3,4,6,8,10,12 ; n=4,6,10)$

L. References 


\section{A. Direct Carbene Polymerization Attempts from TP-Based Diazo Monomer with Six-Methylene Spacer}

The diazo monomer synthesis and direct polymerization attempt was shown in Scheme S1, the monohydroxyl pentakis(hexyloxy)triphenylene was obtained as described in our published paper, ${ }^{1}$ then the synthesis of TP6 based diazo monomer was referred to the literature procedure for the diazoester with side-chain calamitic mesogen reported by Tokita and coworkers. ${ }^{2,3}$<smiles>[R]c1cc2c3cc([R])c([R])cc3c3cc([R])c([R])cc3c2cc1[R]</smiles><smiles>[R]c1cc2c3cc([R])c([R])cc3c3cc(O[13C]([2H])(C)OC(=O)C=N)c([R])cc3c2cc1[R]</smiles>

M6TP6

P6TP6

Scheme S1. Synthesis of diazo monomer M6TP6 with side-chain TP6 discogens and the direct route tried for the preparation of $\mathrm{C} 1$ polymer P6TP6 via Rh-mediated carbene polymerization.

\section{Synthesis of 2-(6-diazoacetoxyhexyloxy)-3,6,7,10,11-pentakis(hexyloxy)triphenylene M6TP6.}

2-hydroxyl-3,6,7,10,11-pentakis(hexyloxy)triphenylene (2.2 g, $3.00 \mathrm{mmol}$ ), 6-bromo-1hexanol (0.66 g, $3.60 \mathrm{mmol}), \mathrm{K}_{2} \mathrm{CO}_{3}(1.3 \mathrm{~g}, 9.00 \mathrm{mmol})$ and $\mathrm{KI}$ (catalytic quantity) were added into $180 \mathrm{~mL} \mathrm{CH} \mathrm{CH}_{3} \mathrm{CN}$. After reaction for $28 \mathrm{~h}$ with stirring in $100{ }^{\circ} \mathrm{C}$ heating bath, the cooled reaction mixture was quenched with $180 \mathrm{~mL}$ saturated $\mathrm{NaHCO}_{3}$ aqueous solution, and then 
extracted with $\mathrm{CH}_{2} \mathrm{Cl}_{2}$. The solvent of the collected organic layer was removed through rotary evaporation, then the crude product was purified by silica-gel column chromatography. After dried in a $50{ }^{\circ} \mathrm{C}$ vacuum oven for $10 \mathrm{~h}, 2.1 \mathrm{~g}$ solid product 2-(6-hydroxylhexyloxy)-3,6,7,10,11pentakis(hexyloxy)triphenylene in pale gray was obtained (yield 83\%).

Then 2-(6-hydroxylhexyloxy)-3,6,7,10,11-pentakis(hexyloxy)triphenylene $(1.69$ g, 2.00 mmol) was dissolved in $60 \mathrm{~mL} \mathrm{CH} \mathrm{Cl}_{2}$, after adding $\mathrm{K}_{2} \mathrm{CO}_{3}(1.38 \mathrm{~g}, 10.00 \mathrm{mmol})$, bromoacetyl bromide $(1.3 \mathrm{~g}, 6.00 \mathrm{mmol})$ was slowly introduced dropwise at $0{ }^{\circ} \mathrm{C}$ under a nitrogen atmosphere. After further stirred at room temperature for $3 \mathrm{~h}$, the reaction mixture was quenched with $40 \mathrm{~mL}$ saturated $\mathrm{NaHCO}_{3}$ aqueous solution and extracted with $\mathrm{CH}_{2} \mathrm{Cl}_{2}$. The solvent of the combined organic layer was removed via rotary evaporation to give a crude product, then further purified by silica-gel column chromatography. After dried at $50{ }^{\circ} \mathrm{C}$ under vacuum for $10 \mathrm{~h}, 1.8 \mathrm{~g}$ pale gray solid product of 2-(6-bromoacetoxyhexyloxy)-3,6,7,10,11-pentakis(hexyloxy)triphenylene was obtained (yield 94\%).

A solution of 2-(6-bromoacetoxyhexyloxy)-3,6,7,10,11-pentakis(hexyloxy)triphenylene (0.96 $\mathrm{g}, 1.00 \mathrm{mmol}$ ) in $2 \mathrm{~mL}$ THF was added to a solution of $N, N^{\prime}$-ditosylhydrazine (DTHZ, $0.68 \mathrm{~g}, 2.00$ mmol) in $18 \mathrm{~mL}$ THF, and the reaction system was cooled to $0 \quad{ }^{\circ} \mathrm{C}$. Then 1,8-Diazabicyclo[5.4.0]undec-7-ene (DBU, $0.75 \mathrm{~mL}, 5.00 \mathrm{mmol}$ ) was slowly added dropwise under a nitrogen atmosphere and stirred at room temperature for $15 \mathrm{~min}$. After quenched with 20 mL saturated $\mathrm{NaHCO}_{3}$ aqueous solution, the reaction mixture was extracted with $\mathrm{CH}_{2} \mathrm{Cl}_{2}$. The solvent of the collected organic layer was removed by rotary evaporation to give a crude product. The further purification of the crude product was carried out by silica-gel column chromatography. Finally, the collected product was dried at $45^{\circ} \mathrm{C}$ under vacuum for $10 \mathrm{~h}$, and $0.684 \mathrm{~g}$ light yellow solid diazo monomer M6TP6 of 2-(6-diazoacetoxyhexyloxy)-3,6,7,10,11-pentakis(hexyloxy) -triphenylene was obtained (yield 75\%). ${ }^{1} \mathrm{H}$ NMR (300 MHz, $\left.\mathrm{CDCl}_{3}\right) \delta(\mathrm{ppm}): 7.85$ (s, 6H, Ar-H), $4.73\left(\mathrm{~s}, 1 \mathrm{H}, \mathrm{OOCC} H \mathrm{~N}_{2}\right), 4.24\left(\mathrm{t}, 14 \mathrm{H}, \mathrm{ArOCH}_{2}, \mathrm{CH}_{2} \mathrm{OOC}\right), 1.90\left(\mathrm{~m}, 12 \mathrm{H}, \mathrm{ArOCH}_{2} \mathrm{CH}_{2}\right)$, 1.63-1.72 (m, 16H, $\left.\mathrm{ArOCH}_{2} \mathrm{CH}_{2} \mathrm{CH}_{2}, \mathrm{CH}_{2} \mathrm{CH}_{2} \mathrm{CH}_{2} \mathrm{OOC}\right), 1.40\left(\mathrm{~m}, 20 \mathrm{H}, \mathrm{CH}_{2}\right), 0.95$ (t, 15H, 
$\left.\mathrm{CH}_{2} \mathrm{CH}_{3}\right)$. FT-IR $\left(\mathrm{cm}^{-1}\right): 3105,2923,2854,2108,1696,1616,1513,1466,1432,1386,1258,1168$, $1025,836,740,601$.

\section{Direct Rh-mediated carbene polymerization attempts.}

Direct Rh-mediated carbene polymerization was tried for the preparation of the stereoregular C1 polymers with high densely substituted triphenylene discogens. A general procedure is described as following: diazoacetate monomer M6TP6 was added to a solution of $\mathrm{Rh}(\mathrm{I})$-catalyst (0.02 eq. to diazo monomer) in selected anhydrous solvent under nitrogen atmosphere. The reaction system was stirred at room temperature around $20{ }^{\circ} \mathrm{C}$, referring to the literature, ${ }^{4-9}$ for a predetermined time. After fulfilling the reaction hours, the reaction mixture solution was transferred dropwise into a mixed solvent of isopropanol and a small quantity of $\mathrm{CH}_{2} \mathrm{Cl}_{2}$, and stirred overnight. Then the precipitate was collected by centrifugal separation, the collected polymer product was dried at $70{ }^{\circ} \mathrm{C}$ under vacuum for $15 \mathrm{~h}$, and then the polymerization performance was evaluated or the solid product was collected. Some experimental attempts of variant polymerization conditions and comparison were carried out, such as solvent, polymerization solution concentration and reaction time. 
Table S1. Experimental attempts of direct Rh-mediated carbene polymerization of the diazo monomer with TP6 discogen tethered through a six-methylene spacer in different solvents.

\begin{tabular}{clll}
\hline Entry & Solvent & Solution appearance & $\begin{array}{l}\text { Polymerization } \\
\text { performance }\end{array}$ \\
\hline 1 & $\mathrm{THF}$ & catalyst partial dissolution & no polymer \\
2 & $\mathrm{CH}_{2} \mathrm{Cl}_{2}$ & homogeneous solution & trace \\
3 & $\mathrm{CHCl}_{3}$ & homogeneous solution & trace \\
4 & $\mathrm{MeOH}^{2} \mathrm{THF}, 1 / 1$ & homogeneous solution & no polymer \\
5 & $\mathrm{MeOH}^{2} \mathrm{CHCl}, 1 / 1$ & homogeneous solution & no polymer \\
6 & $\mathrm{CHCl}_{3} /$ phenetole, $1 / 1$ & homogeneous solution & no polymer \\
7 & $\mathrm{CHCl}_{3} /$ toluene, $1 / 1$ & homogeneous solution & no polymer \\
8 & $\mathrm{CHCl}_{3} /$ acetonitrile, $1 / 1$ & homogeneous solution & no polymer \\
9 & $\mathrm{CHCl}_{3} /$ acetone, $1 / 1$ & homogeneous solution & no polymer \\
\hline
\end{tabular}

Polymerization attempts of diazo monomers in different solvents: The polymerization solution concentration was $50 \%(\mathrm{w} / \mathrm{v})$ and the molar ratio of catalyst/monomer was set to be 1:50, and the reaction time was $24 \mathrm{~h}$. The polymerization degree of monomer was determined by GPC with THF as the eluent. As summarized in Table S1, THF was the first adopted solvent, the polymerization performance was poor and no polymer was harvested (Entry 1), which was ascribed to that the solubility of Rh-catalyst in THF was not good enough to effectively catalyze the polymerization. When the solvent was replaced with $\mathrm{CH}_{2} \mathrm{Cl}_{2}$ (Entry 2) or $\mathrm{CHCl}_{3}$ (Entry 3), the polymerization system displayed a homogeneous solution with both the catalyst and monomer showing good solubility, and a little polymer was obtained. We further attempted to adopt a mixed solvent hoping for some improvement in the polymerization performance. Considering the solubility of catalyst and monomer, one component of the mixed solvents was selected as a good solvent for the Rh-catalyst, namely $\mathrm{CHCl}_{3}$ or $\mathrm{MeOH}$, and the other auxiliary solvent was adopted from THF, phenetole, toluene, acetonitrile or acetone, respectively (Entry 4 9). While no polymer was obtained from the mixture solvent system, manifested polymerization of the discotic mesogenic monomer was not favorable in the investigated mixture solvents. 
Table S2. Experimental attempts of direct Rh-mediated carbene polymerization of the TP6 based diazo monomer in different reactant concentrations and for varied reaction time.

\begin{tabular}{cccl}
\hline Entry & $\begin{array}{c}\text { Reactant } \\
\text { concentration }\end{array}$ & Reaction time & $\begin{array}{l}\text { Polymerization } \\
\text { performance }\end{array}$ \\
\hline 1 & $30 \%$ & $24 \mathrm{~h}$ & no polymer \\
2 & $70 \%$ & $24 \mathrm{~h}$ & no polymer \\
3 & $50 \%$ & $14 \mathrm{~h}$ & $\begin{array}{l}\text { a small quantity of } \\
\text { oligomer } \\
\text { lower yield } \\
\text { polymer }\end{array}$ \\
\hline
\end{tabular}

\section{Polymerization attempts in different concentrations and for varied reaction time:}

Attempts of direct Rh-mediated carbene polymerization of the TP6 based diazo monomer in different reactant concentrations and reaction for varied time were conducted with experimental conditions and polymerization performance listed in Table S2. The molar ratio of catalyst/monomer was fixed at 1:50, and the solvent was anhydrous $\mathrm{CHCl}_{3}$. It can be noted from Table S2 that no polymer was obtained with either $30 \%$ or $70 \%$ concentration, thus too low or too high solution concentration was not conducive to the polymerization (Entry 1,2). Also only a small quantity of low molecular weight oligomer was harvested with a short reaction time (Entry 3).

After contrast experiments and preliminarily optimizing the experimental conditions as described above, anhydrous trichloromethane was chosen as the solvent, the concentration of reaction solution was $50 \%$, the temperature was $20{ }^{\circ} \mathrm{C}$, the reaction time was 24 hours, and the molar ratio of $\mathrm{Rh}(\mathrm{I})$-catalyst to monomer M6TP6 was set to be 1:50. Some polymers were collected with a lower yield (Entry 4 in Table S2). 
Characterization of polymer product P6TP6 from direct polymerization and brief comparison with that of $\mathrm{P6}(\mathrm{TP6})$ from the indirect two-step route.
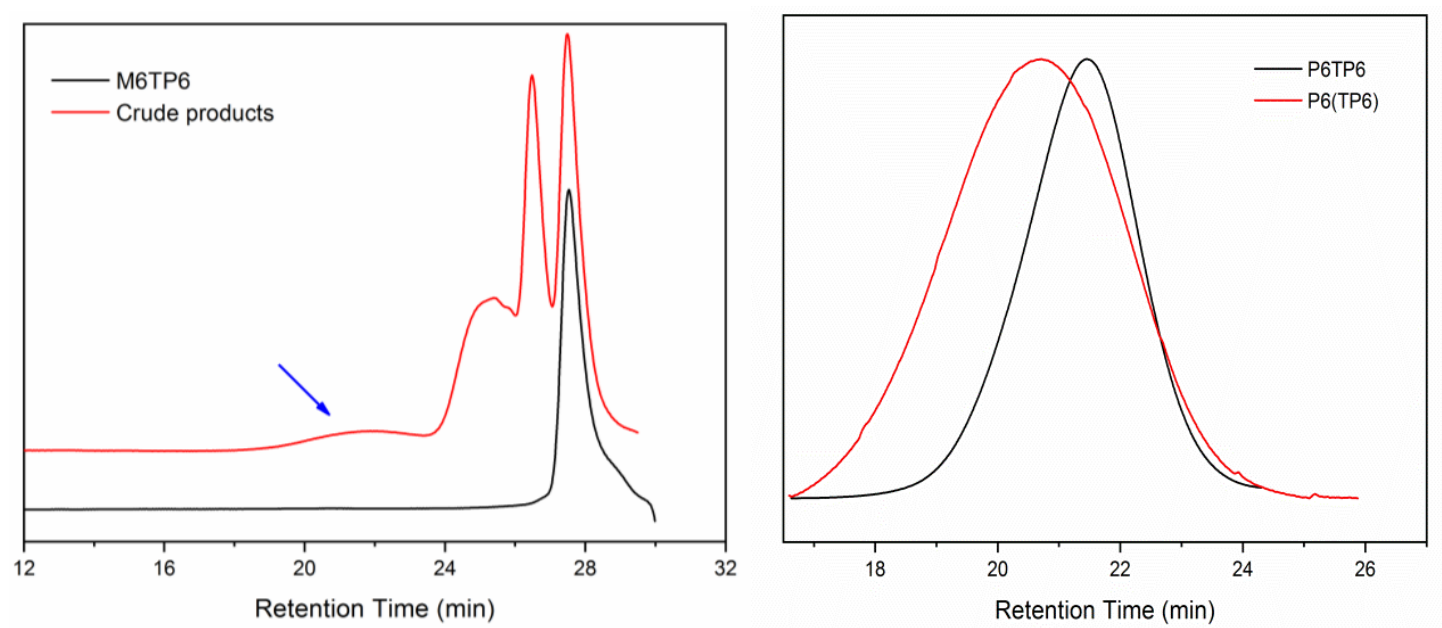

Figure S1. GPC curves comparison of monomer M6TP6, direct polymerization crude products, purified polymer P6TP6 from direct polymerization and polymer P6(TP6) from the indirect two-step route.

Figure S1 illustrates the GPC curves comparison of monomer M6TP6, direct polymerization crude products, purified polymer P6TP6 from direct polymerization and postpolymerization modified polymer product P6(TP6) from the indirect two-step route. The direct polymerization crude products are the untreated polymerization mixtures from the $\mathrm{Rh}(\mathrm{I})$-catalyst mediated carbene polymerization of the monomer M6TP6 under the above preliminarily selected condition. Four peaks appeared in the GPC curve of the direct polymerization crude products, corresponding roughly to the residual unreacted monomers showing almost overlapping peak position to M6TP6, dimers with composition similar to disubstituted fumarate and maleate, low molecular weight oligomers and high molecular weight $\mathrm{C} 1$ polymers, respectively, with decreased retention time, which was consistent to the reaction mechanism of Rh-catalyzed carbene polymerization from diazo monomers as proposed by de Bruin and coworkers. ${ }^{4,5}$ The P6TP6 is the small amount of polymer prepared from the crude products through centrifugal separation purification. And the two-step polymer P6(TP6) is a stereoregular side-chain TP based SDLCP synthesized via the two-step indirect method. Thus GPC analysis confirmed the preparation of high molecular weight 
C1 polymers with TP side-groups, as further demonstrated by NMR and FTIR spectroscopic analysis (Figure S2 and S3), though obtaining the purified polymer P6TP6 with a very low yield of less than $2 \%$ after purification through a centrifugation. The polymer P6TP6 was characterized as $M_{\mathrm{n}}=15,700$ and PDI $=1.20$ as measured by GPC. As shown in Figure S2, the ${ }^{1} \mathrm{H}$ NMR signals of purified polymer P6TP6 showed significantly broadened signal peaks of typical polymer characteristics, in remarkable contrast to the sharp ${ }^{1} \mathrm{H}$ NMR peaks of monomer compound M6TP6. Moreover, no absorbance of the $\mathrm{CH}$ proton in the polymer backbone appeared, which was probably ascribed to the shielding effect of the mesogen-jacketed polymer structure with the densely attached TP6 discogens closely wrapped around the polymer backbone. Furthermore, as shown in Figure S3, the FTIR spectrum of monomer M6TP6 clearly showed the characteristic absorption peak of diazo group $\left(-\mathrm{N}_{2}\right)$ at $2106 \mathrm{~cm}^{-1}$, while this peak completely disappeared in that of the purified polymer P6TP6, which further confirmed the polymerization and effective purification.

Therefore, the Rh-catalyzed carbene polymerization directly from the diazo monomer M6TP6 under the selected reaction conditions could be carried out, while the polymerization efficiency was too poor with a very low yield or even no polymer harvested to serve as a viable synthesis path.

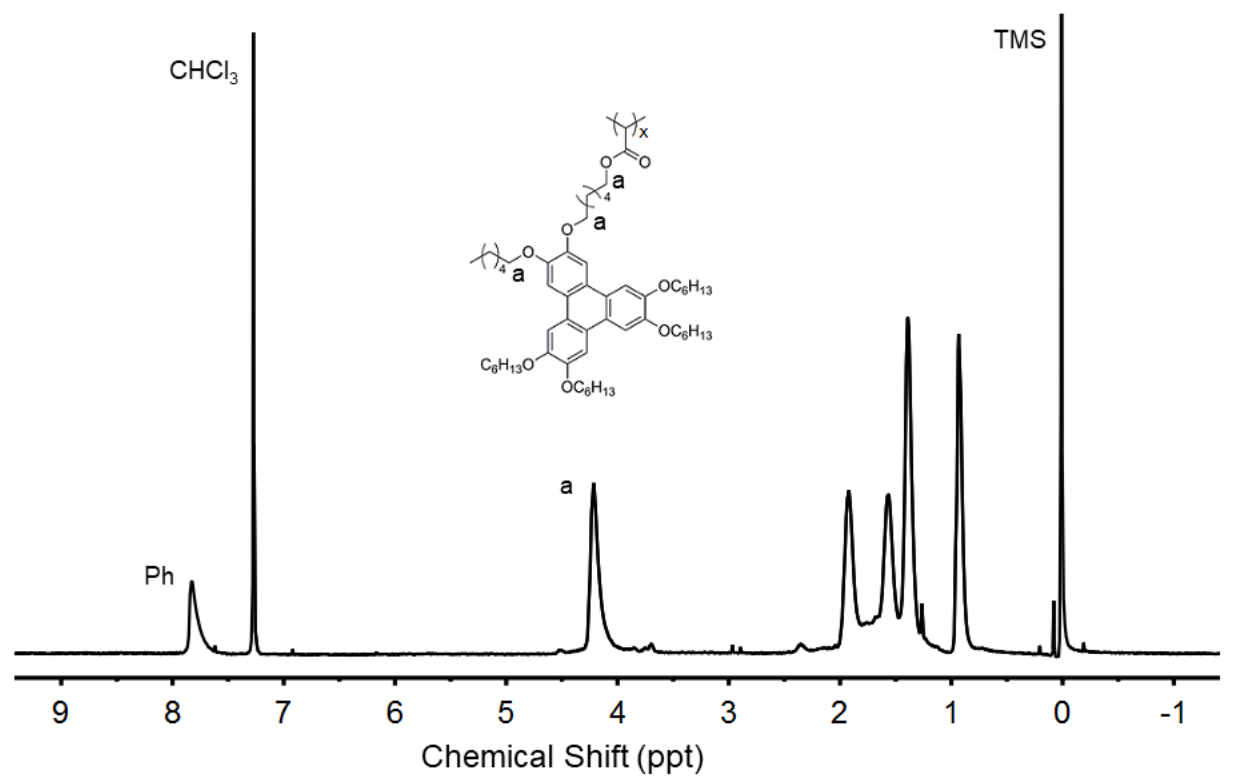

Figure S2. ${ }^{1} \mathrm{H}$ NMR spectrum of purified P6TP6 from directly synthesis route in $\mathrm{CDCl}_{3}$. 


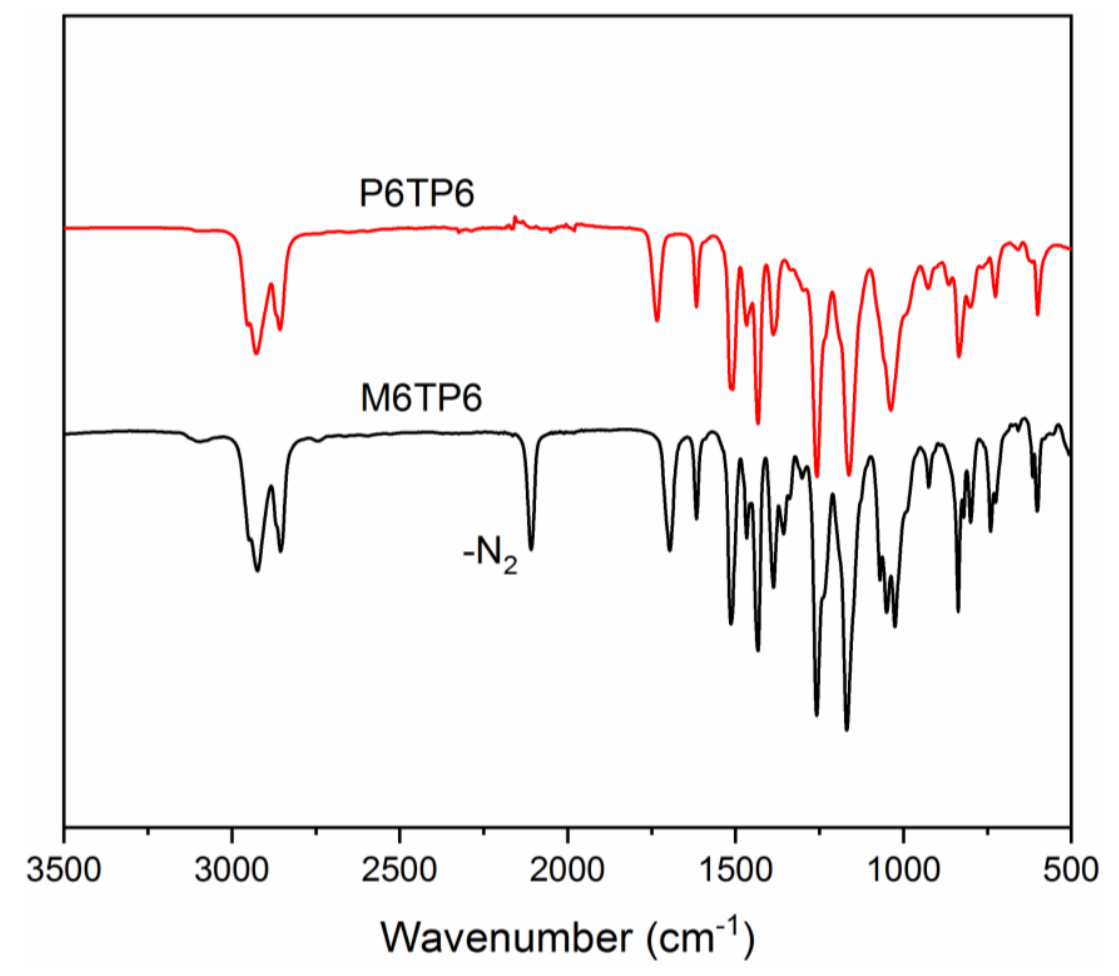

Figure S3. FTIR spectra comparison of monomer M6TP6 and the purified polymer P6TP6.

\section{B. Synthesis and Characterization Results of Other Bromoalkyl Diazoacetate Monomers $(m=3,4,8,10,12)$}

The other diazo monomers were synthesized according to the same synthesis steps of the 6-bromohexyl diazoacetate with characterization results provided below.

3-bromopropyl diazoacetate. Yield 87\%. ${ }^{1} \mathrm{H} \mathrm{NMR}\left(400 \mathrm{MHz}, \mathrm{CDCl}_{3}\right) \delta(\mathrm{ppm}): 4.76(\mathrm{~s}, 1 \mathrm{H}$, $\mathrm{OOCCHN}_{2}$ ), 4.30 (t, 2H, $\left.\mathrm{CH}_{2} \mathrm{OOC}\right), 3.45\left(\mathrm{t}, 2 \mathrm{H}, \mathrm{BrCH}_{2}\right), 2.19$ (t, 2H, $\left.\mathrm{CH}_{2}\right)$. FTIR $\left(\mathrm{cm}^{-1}\right): 2961$, $2111,1728,1689,1394,1335,1227,1154,1004,738$.

4-bromobutyl diazoacetate. Yield 78\%. ${ }^{1} \mathrm{H}$ NMR (400 MHz, $\left.\mathrm{CDCl}_{3}\right) \delta(\mathrm{ppm}): 4.75(\mathrm{~s}, 1 \mathrm{H}$, OOCC $\left.\mathrm{N}_{2}\right), 4.18\left(\mathrm{t}, 2 \mathrm{H}, \mathrm{CH}_{2} \mathrm{OOC}\right), 3.44\left(\mathrm{t}, 2 \mathrm{H}, \mathrm{BrCH}_{2}\right), 1.93\left(\mathrm{~m}, 2 \mathrm{H}, \mathrm{CH}_{2} \mathrm{CH}_{2} \mathrm{OOC}\right), 1.83(\mathrm{~m}$, 2H, $\left.\mathrm{BrCH}_{2} \mathrm{CH}_{2}\right)$. FTIR $\left(\mathrm{cm}^{-1}\right): 3110,2977,2105,1683,1395,1237,1180,1031,738$. 
8-bromooctyl diazoacetate. Yield $85 \% .{ }^{1} \mathrm{H}$ NMR $\left(400 \mathrm{MHz}, \mathrm{CDCl}_{3}\right) \delta(\mathrm{ppm}): 4.75(\mathrm{~s}, 1 \mathrm{H}$, $\left.\mathrm{OOCCHN}_{2}\right), 4.13\left(\mathrm{t}, 2 \mathrm{H}, \mathrm{CH}_{2} \mathrm{OOC}\right), 3.39\left(\mathrm{t}, 2 \mathrm{H}, \mathrm{BrCH}_{2}\right), 1.85\left(\mathrm{~m}, 2 \mathrm{H}, \mathrm{CH}_{2} \mathrm{CH}_{2} \mathrm{OOC}\right), 1.64(\mathrm{~m}$, 2H, $\left.\mathrm{BrCH}_{2} \mathrm{CH}_{2}\right), 1.43\left(\mathrm{~m}, 2 \mathrm{H}, \mathrm{CH}_{2}\left(\mathrm{CH}_{2}\right)_{2} \mathrm{OOC}\right), 1.33\left(\mathrm{~m}, 6 \mathrm{H}, \mathrm{CH}_{2}\right)$. FTIR $\left(\mathrm{cm}^{-1}\right): 3120,2929$, 2858, 2107, 1688, 1460, 1393, 1354, 1239, 1184, 1037, 739, 644.

10-bromodecyl diazoacetate. Yield 80\%. ${ }^{1} \mathrm{H} \mathrm{NMR}\left(400 \mathrm{MHz}, \mathrm{CDCl}_{3}\right) \delta(\mathrm{ppm}): 4.73(\mathrm{~s}, 1 \mathrm{H}$, OOCC $\mathrm{HN}_{2}$ ), 4.14 (t, 2H, $\left.\mathrm{CH}_{2} \mathrm{OOC}\right), 3.41\left(\mathrm{t}, 2 \mathrm{H}, \mathrm{BrCH}_{2}\right), 1.85\left(\mathrm{~m}, 2 \mathrm{H}, \mathrm{CH}_{2} \mathrm{CH}_{2} \mathrm{OOC}\right), 1.63$ (m, 2H, $\left.\mathrm{BrCH}_{2} \mathrm{CH}_{2}\right), 1.42\left(\mathrm{~m}, 2 \mathrm{H}, \mathrm{CH}_{2}\left(\mathrm{CH}_{2}\right)_{2} \mathrm{OOC}\right), 1.29$ (m, 10H, $\left.\mathrm{CH}_{2}\right)$. FTIR $\left(\mathrm{cm}^{-1}\right): 3125,2927$, 2856, 2107, 1690, 1463, 1394, 1357, 1238, 1184, 1024, 739, 643.

12-bromododecyl diazoacetate. Yield 89\%. ${ }^{1} \mathrm{H} \mathrm{NMR}\left(400 \mathrm{MHz}, \mathrm{CDCl}_{3}\right) \delta(\mathrm{ppm}): 4.72(\mathrm{~s}$, $\left.1 \mathrm{H}, \mathrm{OOCCHN} \mathrm{N}_{2}\right), 4.14\left(\mathrm{t}, 2 \mathrm{H}, \mathrm{CH}_{2} \mathrm{OOC}\right), 3.40\left(\mathrm{t}, 2 \mathrm{H}, \mathrm{BrCH}_{2}\right), 1.81\left(\mathrm{~m}, 2 \mathrm{H}, \mathrm{CH}_{2} \mathrm{CH}_{2} \mathrm{OOC}\right), 1.62$ (m, $\left.2 \mathrm{H}, \mathrm{BrCH}_{2} \mathrm{CH}_{2}\right), 1.40\left(\mathrm{~m}, 2 \mathrm{H}, \mathrm{CH}_{2}\left(\mathrm{CH}_{2}\right)_{2} \mathrm{OOC}\right), 1.28\left(\mathrm{~m}, 14 \mathrm{H}, \mathrm{CH}_{2}\right)$. FTIR $\left(\mathrm{cm}^{-1}\right): 3122$, $2921,2858,2107,1692,1465,1392,1351,1242,1184,1024,739,643$. 


\section{C. ${ }^{1}$ H NMR Spectrum of P3(TP6)}

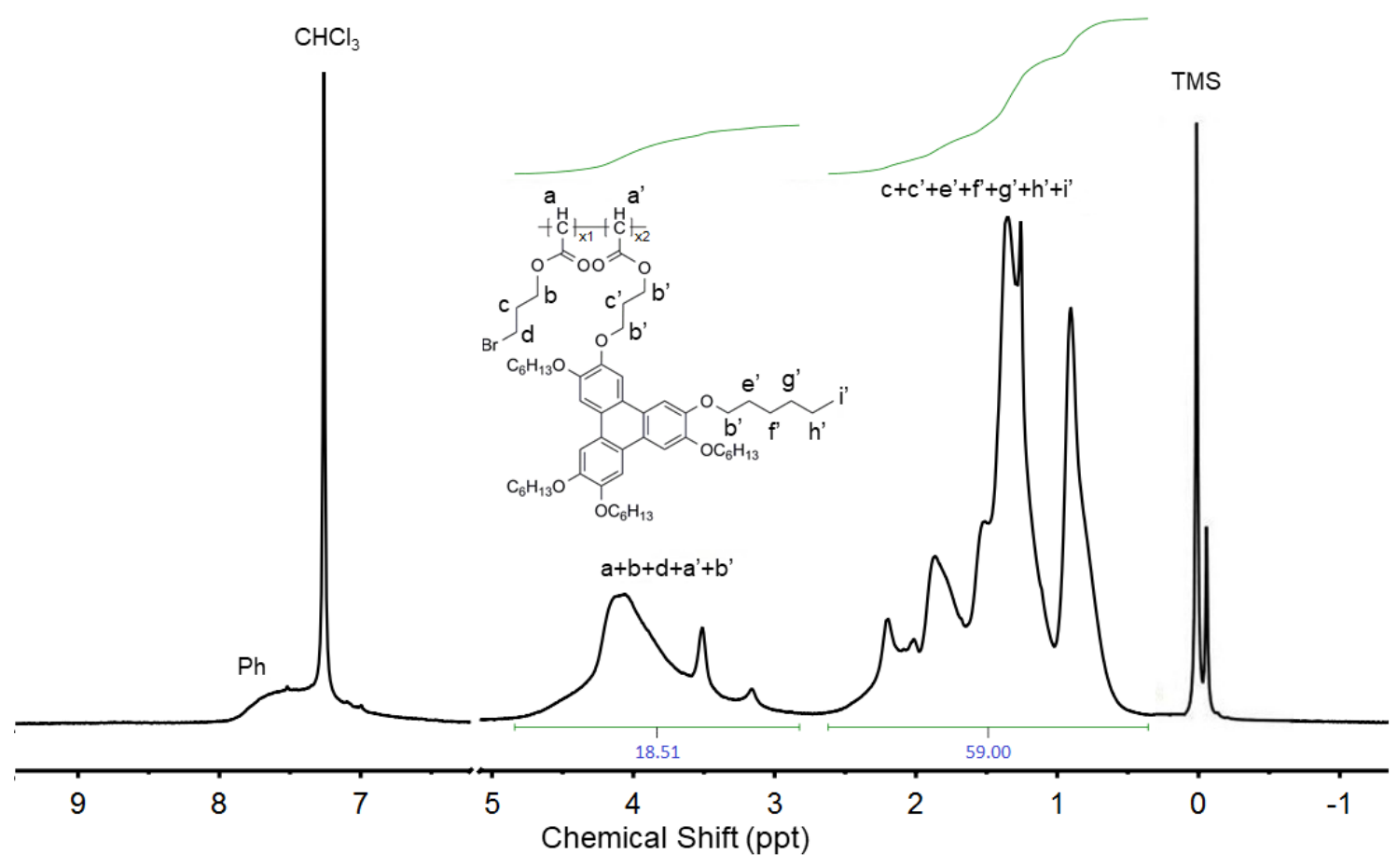

Figure S4. ${ }^{1} \mathrm{H}$ NMR spectrum of $\mathrm{P} 3(\mathrm{TP} 6)$ in $\mathrm{CDCl}_{3}$.

Figure S4 shows the ${ }^{1} \mathrm{H}$ NMR spectrum of P3(TP6) and the corresponding hydrogen signal assignments. It is convenient to estimate the grafting rate of TP side groups from the integral area ratio, so the grafting rate of TP through macrmolecular etherification reaction was calculated to be only $56.4 \%$, with $43.6 \%$ unreacted bromoethyl side groups left. 


\section{D. ${ }^{1} \mathrm{H}$ NMR Spectra Comparison of the Monomer M6TP6 in Various}

\section{Concentrations}

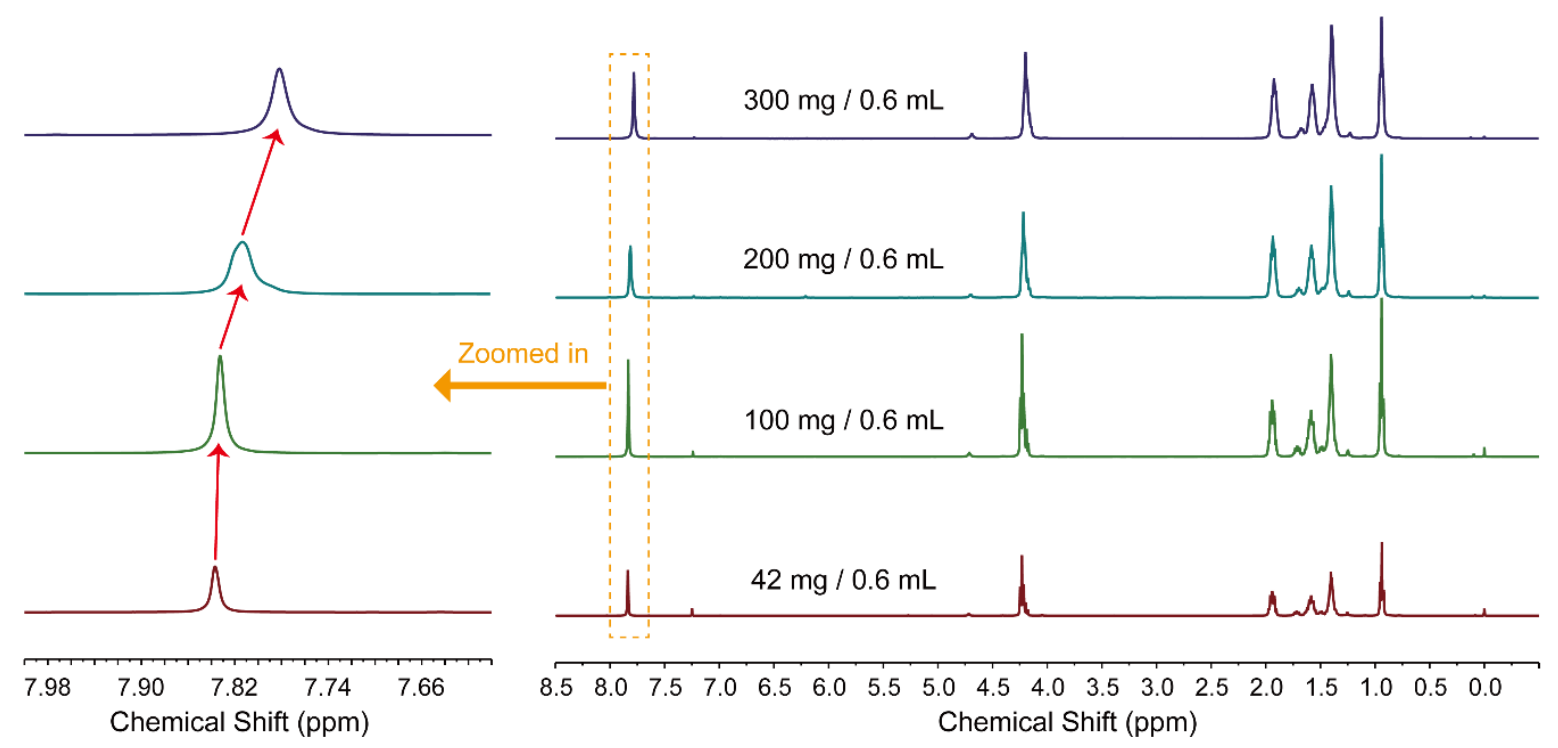

Figure S5. ${ }^{1} \mathrm{H}$ NMR spectra comparison of various concentration solutions of the monomer M6TP6 in $\mathrm{CDCl}_{3}$.

The phenomenon of aggregation caused by $\pi$-stacking induced association of conjugated aromatic rings: Figure S5 shows ${ }^{1} \mathrm{H}$ NMR spectra comparison of diazo monomer M6TP6 with TP side-chain groups at different concentrations of deuterated chloroform $\left(\mathrm{CDCl}_{3}\right)$ solution. It can be seen that the proton chemical shifts of aromatic hydrocarbon move with the increase of solution concentration. When the amount of M6TP6 dissolved in $0.6 \mathrm{~mL} \mathrm{CDCl}_{3}$ increased from $42 \mathrm{mg}$ to $300 \mathrm{mg}$, the chemical shift moved $0.055 \mathrm{ppm}$ upfield from $7.837 \mathrm{ppm}$ to $7.782 \mathrm{ppm}$. This shift is not very remarkable, but compared with the unaltered alkyl proton signals, it has exactly moved and can not be ignored. Therefore, with the increase of concentration in the solution, the TP-based monomer M6TP6 does show aggregation due to $\pi-\pi$ stacking, reminiscent of some literature reports of similar slight shift of aromatic proton signals due to association in solution. ${ }^{10}$ 
E. TGA Analysis Results of P6Br and Pm(TPn) $(m=3,4,6,8,10,12 ; n=4,6$, 10)

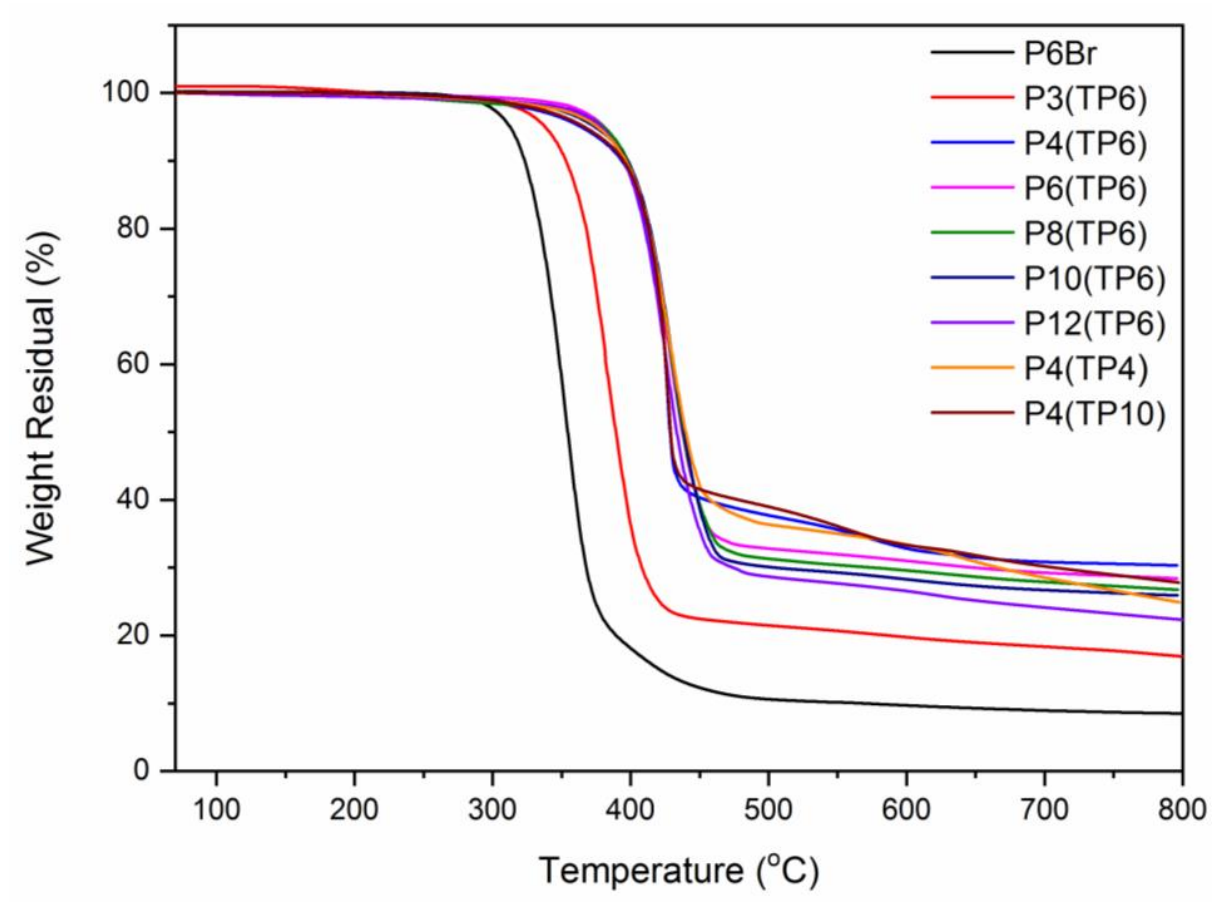

Figure S6. TGA analysis results of a representative precursor polymer P6Br and the TP side-chain C1 polymers $\mathrm{P} m(\mathrm{TP} n)$, with the heating rate of $20^{\circ} \mathrm{C} \mathrm{min}^{-1}$. 
F. Thermal Properties of the Precursor Polymers $\operatorname{PmBr}(m=3,4,6,8,10,12)$

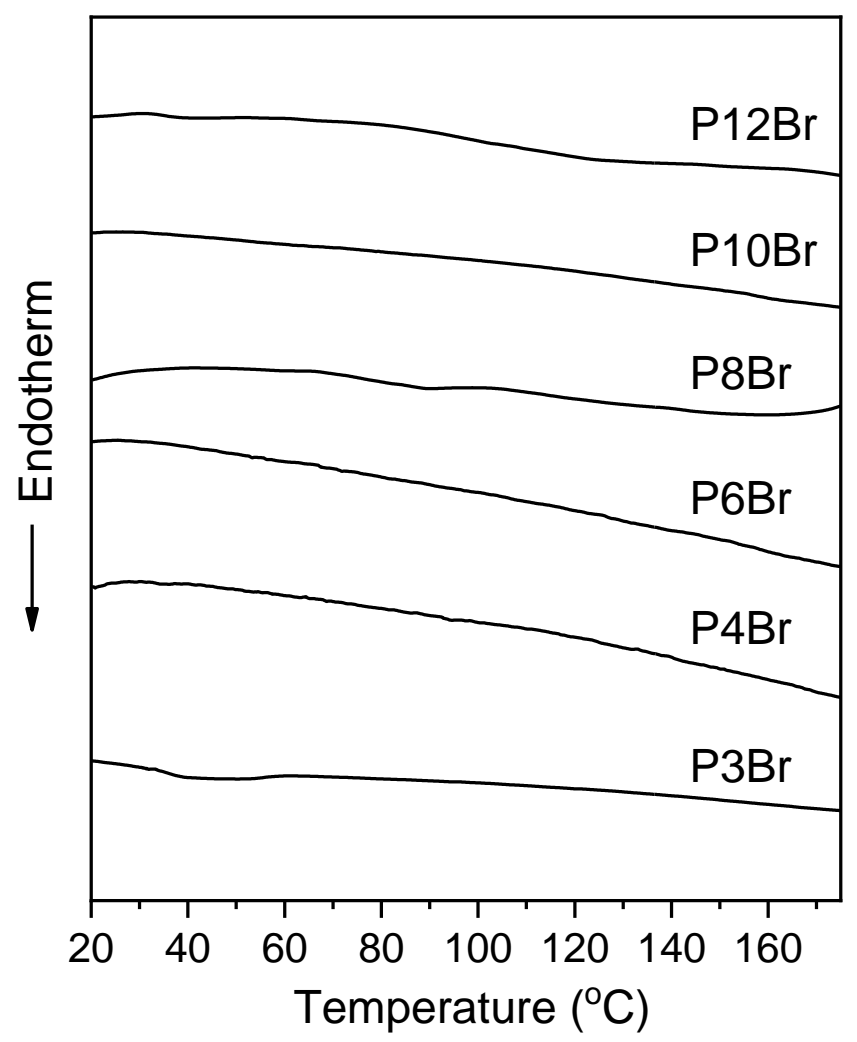

Figure S7. DSC analysis curves of $\mathrm{P} m \mathrm{Br}$, the scanning rate was $10{ }^{\circ} \mathrm{C} \mathrm{min}^{-1}$.

Figure $\mathrm{S} 7$ is the DSC analysis curves of $\mathrm{P} m \mathrm{Br}$ with different spacer lengths, and the scanning rate was $10{ }^{\circ} \mathrm{C} \min ^{-1}$. No significant thermal transition peaks were detected during both heating and cooling processes of DSC measurements. 

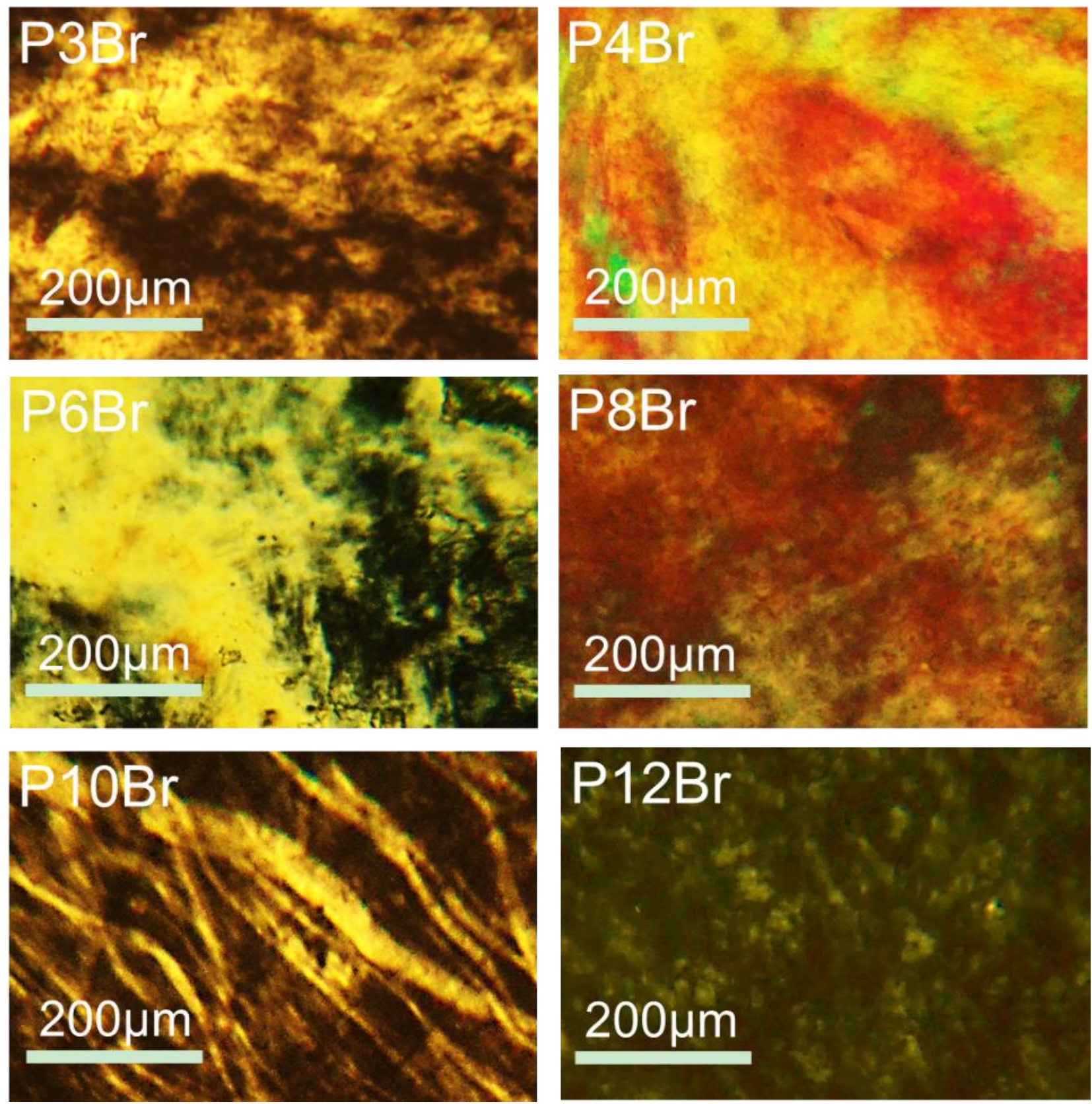

Figure S8. Representative POM images of $\mathrm{P} m \mathrm{Br}$ under crossed polarizers at $25{ }^{\circ} \mathrm{C}$.

Figure $\mathrm{S} 8$ is the representative $\mathrm{POM}$ images of $\mathrm{P} m \mathrm{Br}$ under crossed polarizers at $25{ }^{\circ} \mathrm{C}$. Under the crossed polarized microscope, all precursor polymers exhibited quite strong birefringence from $25{ }^{\circ} \mathrm{C}$ to $250{ }^{\circ} \mathrm{C}$ during both heating and cooling processes. 


\section{H. The SAXS/WAXS Diffractograms and Assignments for the Precursor}

Polymers of $\mathrm{PmBr}(m=3,4,6,8,10,12)$

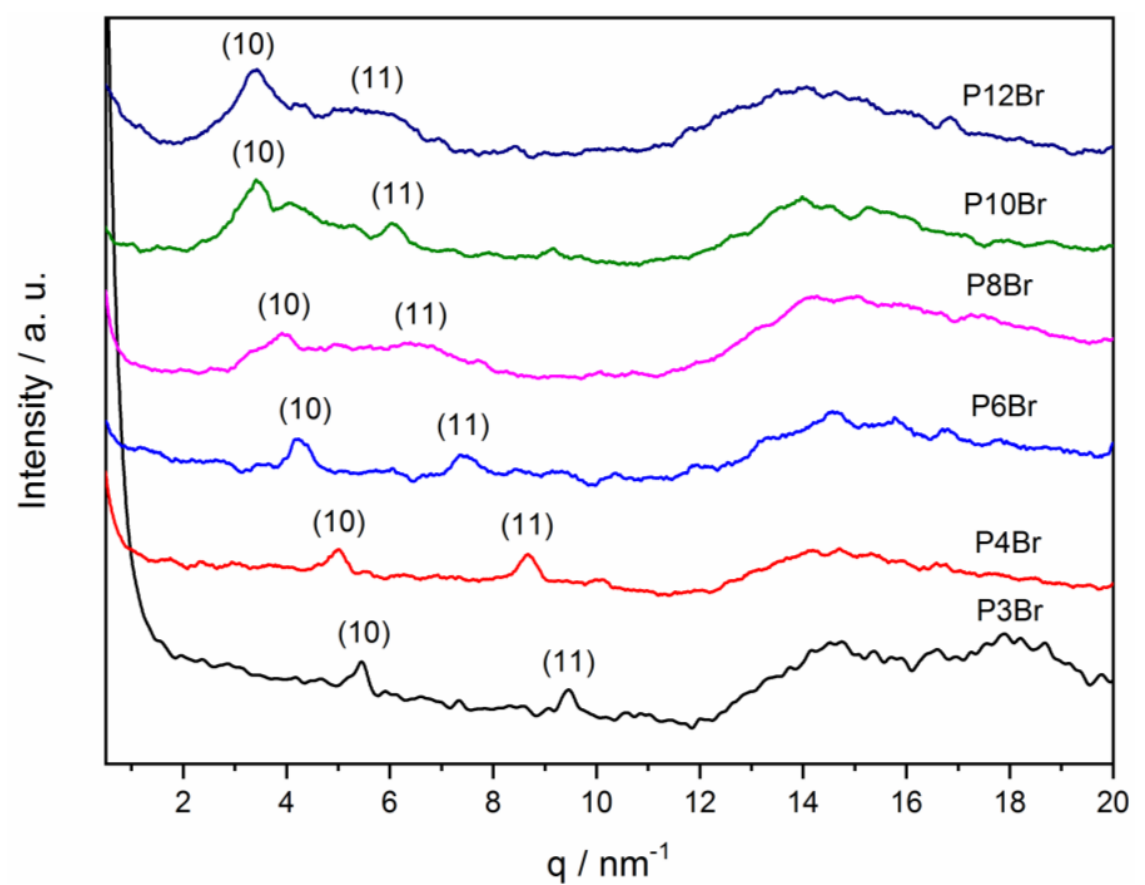

Figure S9. SAXS/WAXS diffractograms of $\mathrm{P} m \mathrm{Br}$ at $25^{\circ} \mathrm{C}$.

Table S4. SAXS/WAXS data and assignments for the precursor polymers of $\mathrm{P} m \mathrm{Br}$ at $25^{\circ} \mathrm{C}$.

\begin{tabular}{|c|c|c|c|c|}
\hline Mesophase & $h k l$ & $\begin{array}{l}d_{\text {obs }} \\
{[\AA]}\end{array}$ & $\begin{array}{l}d_{\text {calc }} \\
{[\AA]}\end{array}$ & $\begin{array}{c}\text { lattice parameter } \\
{[\AA]}\end{array}$ \\
\hline $\mathrm{Col}_{\mathrm{h}}$ & 100 & 11.5 & 11.5 & $a=13.2$ \\
\hline$\left(25^{\circ} \mathrm{C}\right)$ & 110 & 6.6 & 6.6 & \\
\hline $\mathrm{P} 3 \mathrm{Br}$ & & 4.25 (diffuse halo) & & \\
\hline $\mathrm{Col}_{\mathrm{h}}$ & 100 & 12.6 & 12.6 & $a=14.5$ \\
\hline$\left(25^{\circ} \mathrm{C}\right)$ & 110 & 7.3 & 7.3 & \\
\hline $\mathrm{P} 4 \mathrm{Br}$ & & 4.30 (diffuse halo) & & \\
\hline $\mathrm{Col}_{\mathrm{h}}$ & 100 & 14.8 & 14.8 & $a=17.0$ \\
\hline$\left(25^{\circ} \mathrm{C}\right)$ & 110 & 8.6 & 8.6 & \\
\hline $\mathrm{P} 6 \mathrm{Br}$ & & 4.32 (diffuse halo) & & \\
\hline $\mathrm{Col}_{\mathrm{h}}$ & 100 & 16.0 & 16.0 & $a=18.4$ \\
\hline$\left(25^{\circ} \mathrm{C}\right)$ & 110 & 9.2 & 9.2 & \\
\hline $\mathrm{P} 8 \mathrm{Br}$ & & 4.39 (diffuse halo) & & \\
\hline $\mathrm{Col}_{\mathrm{h}}$ & 100 & 18.3 & 18.3 & $a=21.1$ \\
\hline$\left(25^{\circ} \mathrm{C}\right)$ & 110 & 10.6 & 10.6 & \\
\hline $\mathrm{P} 10 \mathrm{Br}$ & & 4.48 (diffuse halo) & & \\
\hline $\mathrm{Col}_{\mathrm{h}}$ & 100 & 18.8 & 18.8 & $a=21.7$ \\
\hline$\left(25^{\circ} \mathrm{C}\right)$ & 110 & 10.8 & 10.8 & \\
\hline $\mathrm{P} 12 \mathrm{Br}$ & & 4.50 (diffuse halo) & & \\
\hline
\end{tabular}



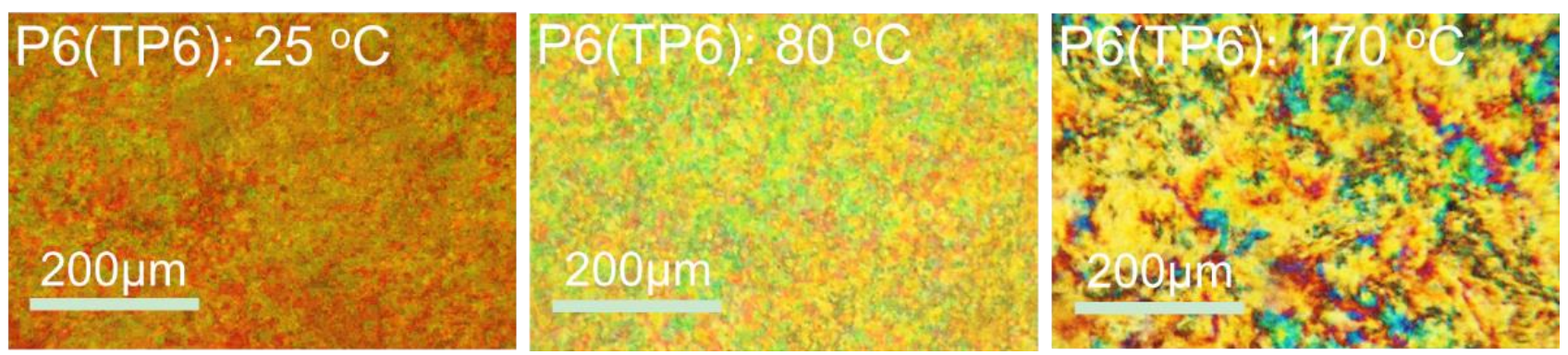

Figure S10. Representative POM images of P6(TP6) at various temperatures.

J. Variable Temperature SAXS/WAXS Diffractograms for P3(TP6) and P12(TP6)
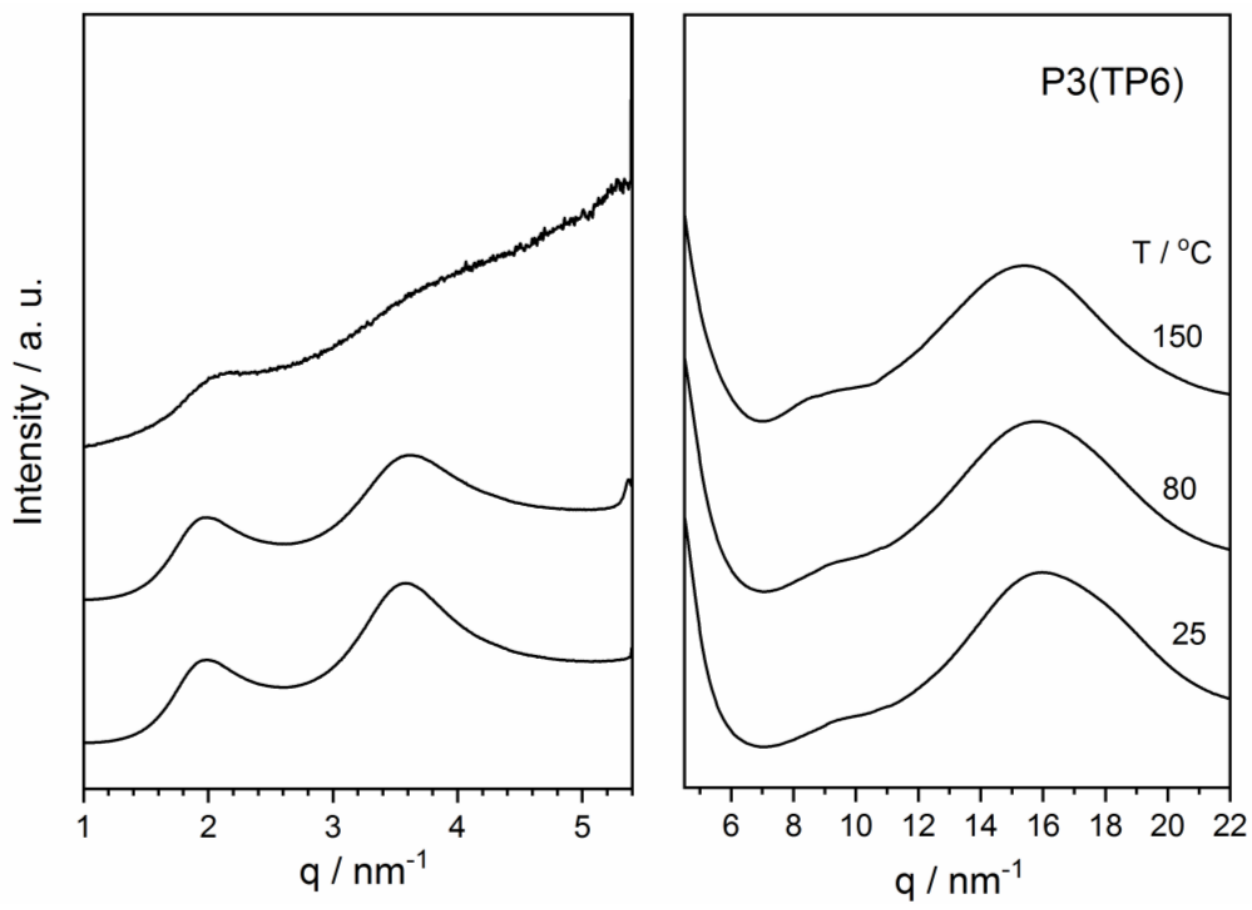

Figure S11. Variable temperature synchrotron radiation SAXS/WAXS diffractograms during 1st heating process of $\mathrm{P} 3(\mathrm{TP} 6)$. 

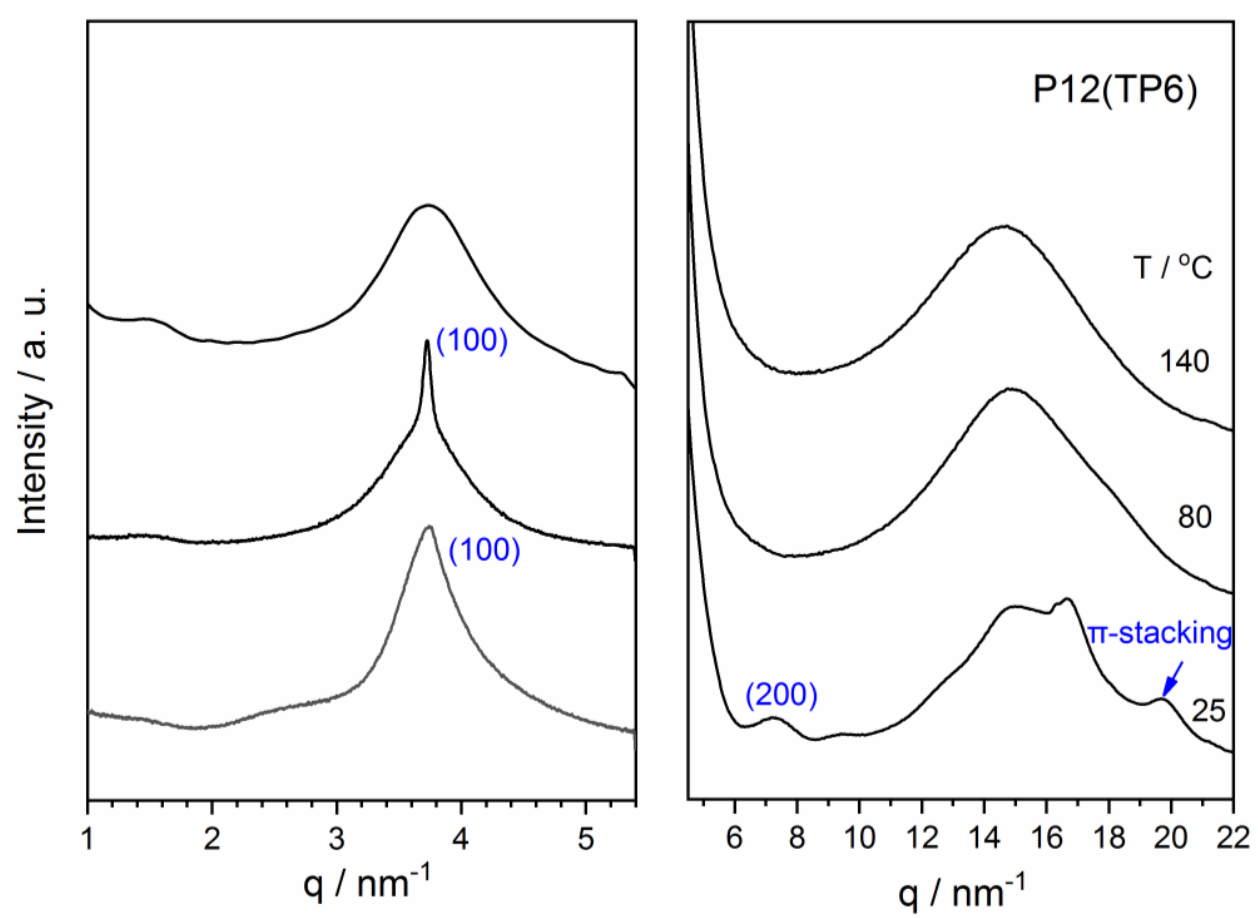

Figure S12. Variable temperature synchrotron radiation SAXS/WAXS diffractograms during 1st heating process of P12(TP6).

\section{K. Synchrotron Radiation X-Ray Scattering Data and Structure Assignments \\ for the Series C1 Polymethylenes of $\operatorname{Pm}(\mathrm{TP} n)(m=3,4,6,8,10,12 ; n=4,6,10)$}

Table S5. Synchrotron radiation X-ray scattering data of P4(TP6) at $25^{\circ} \mathrm{C}$ and $170{ }^{\circ} \mathrm{C}$.

\begin{tabular}{|c|c|c|c|c|c|c|}
\hline Mesophase & $\begin{array}{c}q \\
{\left[\mathrm{~nm}^{-1}\right]}\end{array}$ & $h k l$ & $\begin{array}{l}d_{\mathrm{obs}} \\
{[\AA]}\end{array}$ & $\begin{array}{l}d_{\text {calc }} \\
{[\AA]}\end{array}$ & $\begin{array}{c}\text { lattice parameter } \\
{[\AA]}\end{array}$ & $\rho_{\text {calc }}{ }^{a}$ \\
\hline$D_{\mathrm{h}-\mathrm{s}}$ & 2.0 & 100 & 31.2 & 31.2 & $a=36$ & 1.06 \\
\hline$\left(25^{\circ} \mathrm{C}\right)$ & 3.49 & $110 / 10$ & 18.0 & 18.0 & & $\mathrm{~g} / \mathrm{cm}^{3}$ \\
\hline \multirow[t]{4}{*}{$p 3 m 1$} & 5.32 & 120 & 11.8 & 11.8 & & \\
\hline & 6.04 & $300 / 11$ & 10.4 & 10.4 & & \\
\hline & 14.25 & & 4.41 (diffuse halo) & & & \\
\hline & 17.60 & 001 & 3.57 & & & \\
\hline
\end{tabular}

${ }^{a}$ The density was calculated as $\rho=M \cdot Z /\left(N_{\mathrm{A}} \cdot V_{\text {unit cell }}\right), V_{\text {unit cell }}\left(D_{\mathrm{h}-\mathrm{s}}\right)=a^{2} \cdot c \cdot \sqrt{ } 3 / 2, Z=3(c=$ $3.57 \AA$ ), and $M$ was the molecular weight of a repeat unit of $857 \mathrm{~g} / \mathrm{mol}$.

\begin{tabular}{cccccc}
\hline$C_{\mathrm{h}}$ & 2.03 & 100 & 30.9 & 30.9 & $a=35.7$ \\
$\left(170{ }^{\circ} \mathrm{C}\right)$ & 3.53 & 110 & 17.8 & 17.8 & \\
& & \multicolumn{5}{c}{4.50 (diffuse halo) } \\
\hline
\end{tabular}


Table S6. Synchrotron radiation X-ray scattering data of P6(TP6) at $25^{\circ} \mathrm{C}, 80{ }^{\circ} \mathrm{C}$ and $200{ }^{\circ} \mathrm{C}$.

\begin{tabular}{ccccccc}
\hline Mesophase & $\begin{array}{c}q \\
{\left[\mathrm{~nm}^{-1}\right]}\end{array}$ & $h k l$ & $\begin{array}{c}d_{\text {obs }} \\
{[\AA]}\end{array}$ & $\begin{array}{c}d_{\text {calc }} \\
{[\AA]}\end{array}$ & $\begin{array}{c}\text { lattice parameter } \\
{[\AA]}\end{array}$ & $\rho_{\text {calc }}{ }^{a}$ \\
\hline$D_{\text {ob-s }}$ & 1.41 & 100 & 44.5 & 44.5 & $a=44.8$ & 0.96 \\
$\left(25^{\circ} \mathrm{C}\right)$ & 1.63 & 010 & 38.5 & 38.5 & $b=38.7$ & $\mathrm{~g} / \mathrm{cm}^{3}$ \\
$p 2$ & 2.03 & 110 & 30.9 & 30.9 & $\beta=83.0^{\circ}$ & \\
& 3.41 & 120 & 18.4 & 18.4 & & \\
& 14.25 & \multicolumn{5}{c}{4.41 (diffuse halo) } \\
& 17.70 & 001 & 3.55 & &
\end{tabular}

${ }^{a}$ The density was calculated as $\rho=M \cdot Z /\left(N_{\mathrm{A}} \cdot V_{\text {unit cell }}\right), V_{\text {unit cell }}\left(D_{\mathrm{ob}-\mathrm{s}}\right)=a \cdot b \cdot \sin \beta \cdot c, Z=4(c$ $=3.55 \AA$ ), and $M$ was the molecular weight of a repeat unit of $885 \mathrm{~g} / \mathrm{mol}$.

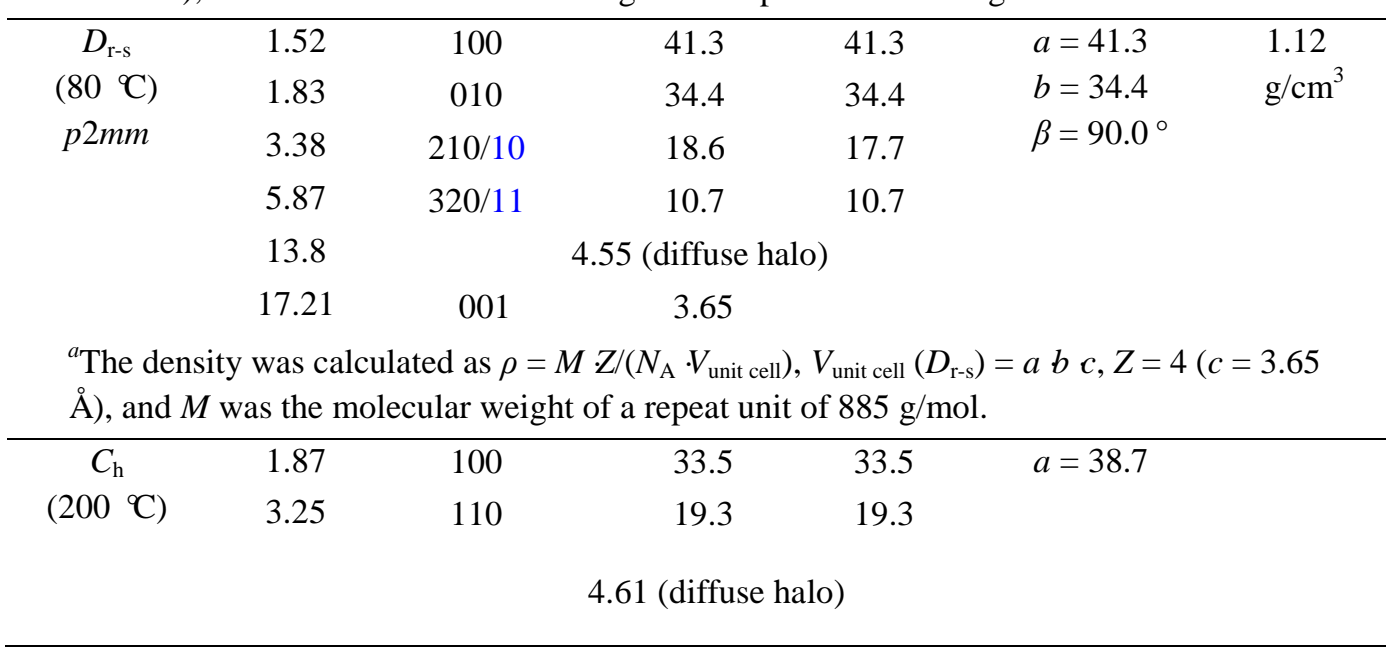

Table S7. Synchrotron radiation X-ray scattering data of P8(TP6) at $25{ }^{\circ} \mathrm{C}$.

\begin{tabular}{|c|c|c|c|c|c|c|}
\hline Mesophase & $\begin{array}{c}q \\
{\left[\mathrm{~nm}^{-1}\right]}\end{array}$ & $h k l$ & $\begin{array}{l}d_{\mathrm{obs}} \\
[\AA]]\end{array}$ & $\begin{array}{l}d_{\text {calc }} \\
{[\AA]}\end{array}$ & $\begin{array}{c}\text { lattice parameter } \\
{[\AA ̊]}\end{array}$ & $\rho_{\text {calc }^{a}}{ }^{a}$ \\
\hline$D_{\mathrm{h} 1-\mathrm{s}}$ & 1.51 & 100 & 41.5 & 41.5 & $a=48.0$ & 1.2 \\
\hline$\left(25^{\circ} \mathrm{C}\right)$ & 3.02 & 200 & 20.7 & 20.7 & & $\mathrm{~g} / \mathrm{cm}^{3}$ \\
\hline \multirow[t]{4}{*}{ p6mm } & 4.00 & 120 & 15.7 & 15.7 & & \\
\hline & 14.25 & \multicolumn{3}{|c|}{4.41 (diffuse halo) } & & \\
\hline & 15.43 & \multicolumn{3}{|c|}{4.07 (shoulder) } & & \\
\hline & 17.75 & 001 & 3.54 & & & \\
\hline
\end{tabular}

${ }^{a}$ The density was calculated as $\rho=M \cdot Z /\left(N_{\mathrm{A}} \cdot V_{\text {unit cell }}\right), V_{\text {unit cell }}\left(D_{\mathrm{h} 1-\mathrm{s}}\right)=a^{2} \cdot c \cdot \sqrt{ } 3 / 2, Z=6(c=$ $3.54 \AA$ ), and $M$ was the molecular weight of a repeat unit of $913 \mathrm{~g} / \mathrm{mol}$. 
Table S8. Synchrotron radiation X-ray scattering data of P10(TP6) at $25{ }^{\circ} \mathrm{C}$.

\begin{tabular}{|c|c|c|c|c|c|c|}
\hline Mesophase & $\begin{array}{c}q \\
{\left[\mathrm{~nm}^{-1}\right]}\end{array}$ & $h k l$ & $\begin{array}{l}d_{\text {obs }} \\
{[\AA]}\end{array}$ & $\begin{array}{l}d_{\text {calc }} \\
{[\AA]}\end{array}$ & $\begin{array}{c}\text { lattice parameter } \\
{[\AA]}\end{array}$ & $\rho_{\text {calc }}{ }^{a}$ \\
\hline \multirow{6}{*}{$\begin{array}{c}D_{\mathrm{h} 1-\mathrm{s}} \\
\left(25^{\circ} \mathrm{C}\right) \\
p 6 m m\end{array}$} & 1.47 & 100 & 42.7 & 42.7 & \multirow[t]{6}{*}{$a=49.3$} & \multirow{6}{*}{$\begin{array}{c}1.2 \\
\mathrm{~g} / \mathrm{cm}^{3}\end{array}$} \\
\hline & 2.95 & 200 & 21.3 & 21.3 & & \\
\hline & 3.90 & 120 & 16.1 & 16.1 & & \\
\hline & 14.15 & \multicolumn{3}{|c|}{4.44 (diffuse halo) } & & \\
\hline & 15.21 & \multicolumn{3}{|c|}{4.13 (shoulder) } & & \\
\hline & 18.00 & 001 & 3.49 & & & \\
\hline
\end{tabular}

${ }^{a}$ The density was calculated as $\rho=M \cdot Z /\left(N_{\mathrm{A}} \cdot V_{\text {unit cell }}\right), V_{\text {unit cell }}\left(D_{\mathrm{h} 1-\mathrm{s}}\right)=a^{2} \cdot c \cdot \sqrt{ } 3 / 2, Z=6(c=$ $3.49 \AA$ ), and $M$ was the molecular weight of a repeat unit of $941 \mathrm{~g} / \mathrm{mol}$.

Table S9. Synchrotron radiation X-ray scattering data of P12(TP6) at $25{ }^{\circ} \mathrm{C}$.

\begin{tabular}{|c|c|c|c|c|c|c|}
\hline Mesophase & $\begin{array}{c}q \\
{\left[\mathrm{~nm}^{-1}\right]}\end{array}$ & $h k l$ & $\begin{array}{l}d_{\text {obs }} \\
{[\AA]}\end{array}$ & $\begin{array}{l}d_{\text {calc }} \\
{[\AA]}\end{array}$ & $\begin{array}{c}\text { lattice parameter } \\
{[\AA]}\end{array}$ & $\rho_{\text {calc }}{ }^{a}$ \\
\hline \multirow{5}{*}{$\begin{array}{c}D_{\mathrm{h}} \\
\left(25^{\circ} \mathrm{C}\right) \\
p 6 m m\end{array}$} & 3.65 & 100 & 17.2 & 17.2 & \multirow[t]{5}{*}{$a=19.8$} & \multirow{5}{*}{$\begin{array}{c}1.2 \\
\mathrm{~g} / \mathrm{cm}^{3}\end{array}$} \\
\hline & 7.30 & 200 & 8.6 & \multirow[t]{4}{*}{8.6} & & \\
\hline & 14.15 & & liffuse & & & \\
\hline & 15.50 & & houlde & & & \\
\hline & 18.16 & 001 & 3.46 & & & \\
\hline \multirow{2}{*}{$\begin{array}{c}D_{\mathrm{hd}} \\
\left(80^{\circ} \mathrm{C}\right)\end{array}$} & 3.62 & 100 & 17.3 & 17.3 & \multirow[t]{2}{*}{$a=19.9$} & \\
\hline & 14.87 & & use ha & & & \\
\hline
\end{tabular}

${ }^{a}$ The density was calculated as $\rho=M \cdot Z /\left(N_{\mathrm{A}} \cdot V_{\text {unit cell }}\right), V_{\text {unit cell }}\left(D_{\mathrm{h}}\right)=a^{2} \cdot c \cdot \sqrt{ } 3 / 2, Z=1(c=3.46 \AA)$, and $M$ was the molecular weight of a repeat unit of $969 \mathrm{~g} / \mathrm{mol}$. 
Table S10. Synchrotron radiation X-ray scattering data of P4(TP4) at $25^{\circ} \mathrm{C}, 80{ }^{\circ} \mathrm{C}$ and $200{ }^{\circ} \mathrm{C}$.

\begin{tabular}{|c|c|c|c|c|c|c|}
\hline Mesophase & $\begin{array}{c}q \\
{\left[\mathrm{~nm}^{-1}\right]}\end{array}$ & $h k l$ & $\begin{array}{l}d_{\mathrm{obs}} \\
{[\AA ̊}\end{array}$ & $\begin{array}{l}d_{\text {calc }} \\
{[\AA \AA]}\end{array}$ & $\begin{array}{l}\text { lattice parameter } \\
[\AA]]\end{array}$ & $\rho_{\text {calc }}{ }^{a}$ \\
\hline \multirow{6}{*}{$\begin{array}{c}D_{\mathrm{ob}-\mathrm{s}} \\
\left(25^{\circ} \mathrm{C}\right) \\
p 2\end{array}$} & 1.44 & 100 & 43.7 & 43.7 & \multirow{6}{*}{$\begin{array}{l}a=43.9 \\
b=35.1 \\
\beta=84^{\circ}\end{array}$} & \multirow{6}{*}{$\begin{array}{l}0.87 \\
\mathrm{~g} / \mathrm{cm}^{3}\end{array}$} \\
\hline & 1.80 & 010 & 34.9 & 34.9 & & \\
\hline & 2.18 & 110 & 28.8 & 28.8 & & \\
\hline & 3.74 & 120 & 16.8 & 16.8 & & \\
\hline & 14.47 & \multicolumn{3}{|c|}{4.34 (diffuse halo) } & & \\
\hline & 17.50 & 001 & 3.59 & & & \\
\hline \multicolumn{7}{|c|}{$\begin{array}{l}{ }^{a} \text { The density was calculated as } \rho=M \cdot Z /\left(N_{\mathrm{A}} \cdot V_{\text {unit cell }}\right), V_{\text {unit cell }}\left(D_{\text {ob-s-s }}\right)=a \cdot b \cdot \sin \beta \cdot c, Z=4(c= \\
3.59 \AA) \text {, and } M \text { was the molecular weight of a repeat unit of } 717 \mathrm{~g} / \mathrm{mol} .\end{array}$} \\
\hline \multirow{5}{*}{$\begin{array}{c}D_{\mathrm{r}-\mathrm{s}} \\
\left(80^{\circ} \mathrm{C}\right) \\
p 2 \mathrm{~mm}\end{array}$} & 1.77 & 100 & 35.5 & 35.5 & \multirow{5}{*}{$\begin{array}{l}a=35.5 \\
b=30.6 \\
\beta=90.0^{\circ}\end{array}$} & \multirow{5}{*}{$\begin{array}{l}1.16 \\
\mathrm{~g} / \mathrm{cm}^{3}\end{array}$} \\
\hline & 2.05 & 010 & 30.6 & 30.6 & & \\
\hline & 3.72 & 200 & 16.9 & 17.7 & & \\
\hline & & \multicolumn{3}{|c|}{4.43 (diffuse halo) } & & \\
\hline & & 001 & 3.67 & & & \\
\hline \multicolumn{7}{|c|}{$\begin{array}{l}{ }^{a} \text { The density was calculated as } \rho=M \cdot Z /\left(N_{\mathrm{A}} \cdot V_{\text {unit cell }}\right), V_{\text {unit cell }}\left(D_{\mathrm{r}-\mathrm{s}}\right)=a \cdot b \cdot c, Z=4(c=3.67 \\
\AA \text { A), and } M \text { was the molecular weight of a repeat unit of } 717 \mathrm{~g} / \mathrm{mol} \text {. }\end{array}$} \\
\hline \multirow{3}{*}{$\begin{array}{c}C_{\mathrm{h}} \\
\left(200^{\circ} \mathrm{C}\right)\end{array}$} & 2.01 & 100 & 31.2 & 31.2 & \multirow[t]{3}{*}{$a=36.0$} & \\
\hline & 3.49 & 110 & 18.0 & 18.0 & & \\
\hline & & & ) (diffu & & & \\
\hline
\end{tabular}

Table S11. Synchrotron radiation X-ray scattering data of P4(TP10) at $25{ }^{\circ} \mathrm{C}$ and $200{ }^{\circ} \mathrm{C}$.

\begin{tabular}{|c|c|c|c|c|c|c|}
\hline Mesophase & $\begin{array}{c}q \\
{\left[\mathrm{~nm}^{-1}\right]}\end{array}$ & $h k l$ & $\begin{array}{l}d_{\mathrm{obs}} \\
{[\AA]}\end{array}$ & $\begin{array}{l}d_{\text {calc }} \\
[\AA]]\end{array}$ & $\begin{array}{c}\text { lattice parameter } \\
{[\AA]}\end{array}$ & $\rho_{\text {calc }}{ }^{a}$ \\
\hline \multirow{4}{*}{$\begin{array}{c}D_{\mathrm{h}-s 1} \\
\left(25^{\circ} \mathrm{C}\right) \\
p 3 m 1\end{array}$} & 1.79 & 100 & 35.1 & 35.1 & $a=40.5$ & 1.18 \\
\hline & 3.10 & 110 & 20.3 & 20.3 & & $\mathrm{~g} / \mathrm{cm}^{3}$ \\
\hline & 15.21 & \multicolumn{3}{|c|}{4.13 (diffuse halo) } & & \\
\hline & 18.15 & 001 & 3.47 & & & \\
\hline
\end{tabular}

${ }^{a}$ The density was calculated as $\rho=M \cdot Z /\left(N_{\mathrm{A}} \cdot V_{\text {unit cell }}\right), V_{\text {unit cell }}\left(D_{\mathrm{h}-\mathrm{s} 1}\right)=a^{2} \cdot c \cdot \sqrt{3} / 2, Z=3(c=$ $3.36 \AA$ ), and $M$ was the molecular weight of a repeat unit of $1137 \mathrm{~g} / \mathrm{mol}$.

\begin{tabular}{cccccc}
\hline$C_{\mathrm{h}}$ & 1.81 & 100 & 34.7 & 34.7 & $a=40.1$ \\
$\left(20{ }^{\circ} \mathrm{C}\right)$ & 3.14 & 110 & 20.0 & 20.0 & \\
& 4.80 & 120 & 13.1 & 13.1 & \\
& \multicolumn{5}{c}{4.39 (diffuse halo) } \\
\hline
\end{tabular}




\section{References}

(1) Mu, B.; Wu, B.; Pan, S.; Fang, J. L.; Chen, D. Z. Macromolecules 2015, 48, 2388-2398.

(2) Tokita, M.; Shikinaka, K.; Hoshino, T.; Fujii, K.; Mikami, J.; Koshimizu, N.; Sakajiri, K.; Kang, S.; Watanabe, J.; Shigehara, K. Polymer 2013, 54, 995-998.

(3) Koshimizu, N.; Aizawa, Y.; Sakajiri, K.; Shikinaka, K.; Shigehara, K.; Kang, S.; Tokita, M. Macromolecules 2015, 48, 3653-3661.

(4) Hetterscheid, D. G. H.; Hendriksen, C.; Dzik, W. I.; Smits, J. M. M.; van Eck, E. R. H.; Rowan, A. E.; Busico, V.; Vacatello, M.; Castelli, V. V. A.; Segre, A.; Jellema, E.; Bloemberg, T. G.; de Bruin, B. J. Am. Chem. Soc. 2006, 128, 9746-9752.

(5) Jellema, E.; Budzelaar, P. H. M.; Reek, J. N. H.; de Bruin, B. J. Am. Chem. Soc. 2007, 129, 11631-11641.

(6) Walters, A. J. C.; Smits, J. M. M.; Reek, J. N. H.; de Bruin, B. Organometallics 2010, 29, 2823-2826.

(7) Jongerius, A. L.; Ekenstein, G. A. V.; Mookhoek, S. D.; Dingemans, T. J.; Reingruber, E. M.; Chojnacka, A.; Schoenmakers, P. J.; Sprenkels, R.; Eck, E. R. H. V.; Reek, J. N. H.; de Bruin, B. Macromolecules 2010, 43, 8892-8903.

(8) Suarez, A. I. O.; del Río, M. P.; Remerie, K.; Reek, J. N. H.; de Bruin, B. ACS Catal. 2012, 2 , 2046-2059.

(9) Walters, A. J. C.; Jellema, E.; Finger, M.; Aarnoutse, P.; Smits, J. M. M.; Reek, J. N. H.; de Bruin, B. ACS Catal. 2012, 2, 246-260.

(10) Kato, S.; Takahashi, N.; Tanaka, H.; Kobayashi, A.; Yoshihara, T.; Tobita, S.; Yamanobe, T.; Uehara, H.; Nakamura, Y. Chem. Eur. J. 2013, 19, 12138-12151. 